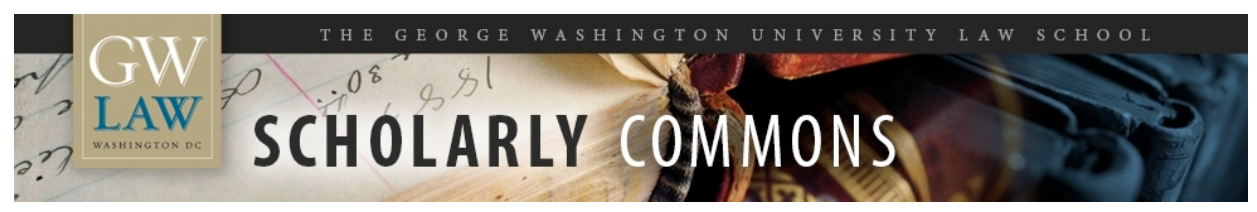

\title{
Self-Determination in Regional Human Rights Law: From Kosovo to Cameroon
}

Dinah L. Shelton

George Washington University Law School, dshelton@law.gwu.edu

Follow this and additional works at: https://scholarship.law.gwu.edu/faculty_publications

Part of the Law Commons

\section{Recommended Citation}

Dinah Shelton, Self-Determination in Regional Human Rights Law: From Kosovo to Cameroon, 105 AM. J. INT'L L. 60 (2011).

This Article is brought to you for free and open access by the Faculty Scholarship at Scholarly Commons. It has been accepted for inclusion in GW Law Faculty Publications \& Other Works by an authorized administrator of Scholarly Commons. For more information, please contact spagel@law.gwu.edu. 
combined with an unfavorable balance of geopolitical forces from the Palestinian perspective, might still make it imprudent to issue such a declaration and thus outweigh the legitimacy rationale that has built support for the Kosovo path to independence and sovereignty. In effect, the benefits of legitimacy and legality perform a role for the Palestinians similar to that of Banquo's ghost in Macbeth.

\section{SELF-DETERMINATION IN REGIONAL HUMAN RIGHTS LAW: FROM KOSOVO TO CAMEROON}

\section{Dinah Shelton*}

The right of self-determination has long been celebrated for bringing independence and selfgovernment to oppressed groups, yet it remains a highly controversial norm of international law. From the breakup of the Austro-Hungarian and Ottoman Empires after World War I to the struggle of colonial territories for independence following World War II and the later dissolution of the former Yugoslavia, there has been an unavoidable conflict between the efforts of peoples to achieve independence and the demands of existing states to preserve their territorial integrity. ${ }^{1}$ The UN Declaration on Principles of International Law reflects this tension. ${ }^{2}$ It gives the principle of self-determination universal scope as a right belonging to undefined "peoples" but rejects any secession from independent states "conducting themselves in compliance with the principle of equal rights and self-determination of peoples . . . and thus possessed of a government representing the whole people belonging to the territory without distinction as to race, creed or colour." The 1993 Vienna Declaration adopted by the World Conference on Human Rights similarly affirmed the universal application of the right of selfdetermination to peoples under colonial or other forms of alien domination or foreign occupation, but also specified, in conformity with the Declaration of Principles, that the right

shall not be construed as authorizing or encouraging any action which would dismember or impair, totally or in part, the territorial integrity or political unity of sovereign and independent states conducting themselves in compliance with the principle of equal rights and self-determination of peoples and thus possessed of a government representing the whole people. ${ }^{3}$

In its recent Kosovo advisory opinion, ${ }^{4}$ the International Court of Justice (ICJ) found no prohibition of unilateral declarations of independence in either general international law or in the practice of the UN Security Council. ${ }^{5}$ In fact, the Court noted that "during the second half

* Of the Board of Editors.

${ }^{1}$ See Antonio Cassese, Self-Determination of Peoples: A Legal Reappraisal (1995).

${ }^{2}$ Declaration on Principles of International Law Concerning Friendly Relations and Co-operation Among States in Accordance with the Charter of the United Nations, GA Res. 2625 (XXV), annex (Oct. 24, 1970).

${ }^{3}$ Vienna Declaration and Progamme of Action, para. 2, UN Doc. A/CONF.157/23 (July 12, 1993).

${ }^{4}$ Accordance with International Law of the Unilateral Declaration of Independence in Respect of Kosovo, Advisory Opinion (Int'l Ct. Justice July 22, 2010). ICJ documents cited in this essay are available on the ICJ Web site, http://www.icj-cij.org.

5 "[N]o general prohibition against unilateral declarations of independence may be inferred from the practice of the Security Council." Id., para. 81. 
of the twentieth century, the international law of self-determination developed in such a way as to create a right to independence for the peoples of non-self-governing territories and peoples subject to alien subjugation, domination and exploitation." ${ }^{6}$ Moreover, the Court observed, a great many new states have come into existence as a result of the exercise of this right and also have issued declarations of independence outside the colonial context. Thus, state practice did not point to the emergence in international law of a new rule that prohibits making a declaration of independence in such cases. Nonetheless, the Court noted sharp disagreements about "[w]hether, outside the context of non-self-governing territories and peoples subject to alien subjugation, domination and exploitation, the international law of self-determination confers upon part of the population of an existing State a right to separate from that State." Similar differences were found to exist regarding whether international law provides for a right of "remedial secession" and, if so, in what circumstances. The Court declined to resolve these debates, finding it was unnecessary to do so in order to respond to the question posed by the General Assembly, which concerned only whether or not the declaration of independence was in accordance with international law.

The issues that the Court did not address remain significant ones. They have been sources of conflict, practice, and jurisprudence in many regions of the world. Africa, for example, continues to confront the aftermath of colonialism, during which arbitrary boundaries were drawn, dividing some peoples and forcing others together, sometimes despite a tradition of mutual hostility or enmity. To resolve one such problem, on January 9, 2011, residents of southern Sudan are scheduled to vote on whether to secede or remain part of the largest country on the continent. ${ }^{8}$ Although included as part of a peace agreement, the referendum has been repudiated by many in the region and may yet be postponed or canceled. ${ }^{9}$ The regional African Union is caught between its Constitutive Act, which enshrines as a founding principle "respect of borders existing on achievement of independence," 10 and its significant role as a signatory and guarantor of the peace agreement. ${ }^{11}$ The potential for secession of part of Sudan following the referendum may be viewed by some through the prism of decolonization, in order to legitimize the resulting independence. Supporters of secession may note that in its

${ }^{6}$ Id., para. 79 (citing Legal Consequences for States of the Continued Presence of South Africa in Namibia (South West Africa) Notwithstanding Security Council Resolution 276 (1970), Advisory Opinion, 1971 ICJ REP. 16, paras. 52-53 (June 21); East Timor (Port. v. Austl.), 1995 ICJ REP. 90, para. 29 (June 30); Legal Consequences of the Construction of a Wall in the Occupied Palestinian Territory, Advisory Opinion, 2004 ICJ REP. 136, para. 88 (July 9)).

${ }^{7} I d$., para. 82.

${ }^{8}$ The referendum was stipulated under the Comprehensive Peace Agreement of 2005, which formally ended a twenty-year civil war between the government in Khartoum and the south's Sudan People's Liberation Movement Army. See Comprehensive Peace Agreement Between the Government of the Republic of Sudan and the Sudan People's Liberation Movement/Sudan People's Liberation Army (Jan. 9, 2005), at http://www.aec-sudan.org/ docs/cpa/cpa-en.pdf.

${ }^{9}$ The second Afro-Arab summit, held in Sirte, Libya, on October 10,2010, rejected the potential secession and underlined the importance of protecting Sudan's territorial integrity, explaining that the failure to do so would lead to the disintegration of the whole continent. See http://www.afro-arabsummit.com.

${ }^{10}$ Constitutive Act of the African Union, Art. 4(b), July 11, 2000, OAU Doc. CAB/LEG/23.15. The founding documents and other treaties, conventions, and instruments of the African Union, as well as some instruments of its predecessor organization, the Organization of African Unity (OAU), are available at http://www.africa-union. org/root/au/Documents/Treaties/treaties.htm.

${ }^{11}$ Jean Ping, AU Chairperson, Remarks at the UN High Level Meeting on Sudan (Sept. 24, 2010), at http:// blogs.ssrc.org/sudan/. 
Kosovo opinion the ICJ recognized the legality of independence for peoples subject to alien subjugation, domination, and exploitation, but did not attempt to resolve the diversity of views outside that context.

In contrast to Sudan and the potential independence of its southern region, indigenous and tribal peoples in Africa and the Americas have refrained from claiming independence, seeking instead to obtain internal self-determination and, in particular, control over their ancestral lands and resources. The right to such internal self-determination is recognized by the two international instruments devoted to the rights of indigenous and tribal peoples: the International Labour Organization's Convention (No. 169) Concerning Indigenous and Tribal Peoples in Independent Countries ${ }^{12}$ and the UN Declaration on the Rights of Indigenous Peoples. ${ }^{13}$ The UN Declaration explicitly recognizes indigenous peoples' right to selfdetermination. ${ }^{14}$ For its part, ILO Convention No. 169 contributes to defining "peoples" by regarding self-identification as the fundamental criterion, but specifies that the use of the term "shall not be construed as having any implications as regards the rights which may attach to the term under international law." 15 While thus seeming to refute the right of indigenous peoples to self-determination, the Convention nonetheless recognizes the aspirations of indigenous peoples to control their own institutions, ways of life, and economic development "within the framework of the state in which they live." ${ }^{16}$ In fact, the major part of ILO Convention No. 169 can be characterized as setting forth elements of internal self-determination for indigenous and tribal peoples, as groups entitled to special treatment. ${ }^{17}$

Taking into account these global instruments, the African and American regional human rights systems have contributed to the law of self-determination. As this essay will reveal, the two regional systems have distinguished internal from external self-determination, and indicated the different circumstances under which each variation of the right applies. The essay begins with a look at the relevant human rights provisions of the two systems, after which it turns to the case law concerning secession claims; the discussion on secession is limited to Africa because no case of this type has come before the American human rights institutions. It then 12 International Labour Organization, Convention Concerning Indigenous and Tribal Peoples in Independent
Countries (No. 169), June 27, 1989, at http://www.ilo.org/ilolex/ [hereinafter ILO Convention No. 169]. For an
overview of the ILO's concern with indigenous peoples, see LUIS RODRIGUEZ-PINERO, INDIGENOUS PEOPLES,
POSTCOLONIALISM, AND INTERNATIONAL LAW: THE ILO REGIME (1919-1989) (2005).
${ }^{13}$ Declaration on the Rights of Indigenous Peoples, GA Res. 61/295, annex (Sept. 13, 2007).
${ }^{14}$ Id., Art. 3 ("Indigenous peoples have a right to self-determination. By virtue of that right they freely determine
their political status and freely pursue their economic, social and cultural development."). The Declaration on the
Rights of Indigenous Peoples also affirms indigenous peoples' rights to autonomy and self-government, culture,
traditional knowledge, development, education, social services, the environment, and ownership of traditional
lands and natural resources.

${ }^{15}$ ILO Convention No. 169, supra note 12.

${ }^{16} I d$., pmbl., para. 5.

17 Notably, the World Bank Operational Manual, OP 4.10 (July 2005), at http://go.worldbank.org/ 2G5SSZAET0, also recognizes the customary rights of indigenous peoples over lands and resources, and affirms the principle of their "free, prior, and informed consultation" in relation to bank-funded projects affecting them. See also Committee on the Elimination of Racial Discrimination, General Recommendation No. 23, Indigenous Peoples, para. 5 (Aug. 18, 1997), Report of the Committee on the Elimination of Racial Discrimination, UN GAOR, $52 \mathrm{~d}$ Sess., Supp. No. 18, Annex V, UN Doc. A/52/18 (1997), calling upon states, inter alia, to "recognize and protect the rights of indigenous peoples to own, develop, control and use their communal lands, territories and resources." 
looks at the special self-determination rights of indigenous and tribal peoples, and at the corresponding special state duties owed them. As will be noted, the jurisprudence of the two systems provides some of the answers that the ICJ declined to give in the Kosovo opinion. The final part refers to the written submissions of African and American states in the Kosovo proceedings.

\section{THE RIGHT TO SELF-DETERMINATION IN REGIONAL HUMAN RIGHTS INSTRUMENTS}

In the Inter-American system, neither the American Declaration on the Rights and Duties of $\mathrm{Man}^{18}$ nor the American Convention on Human Rights ${ }^{19}$ mentions a right of selfdetermination. Language to include this right in the Draft American Declaration on the Rights of Indigenous Peoples under negotiation in the Organization of American States remains in brackets without consensus. ${ }^{20}$ In contrast to the American and European human rights instruments, ${ }^{21}$ the African Charter on Human and Peoples' Rights ${ }^{22}$ contains a detailed right of peoples to self-determination. Given the context of decolonization in Africa and the struggle against apartheid in Southern Africa, both of which are referred to in the preamble to the African Charter, ${ }^{23}$ it is not surprising to find the right expressed. As defined in African Charter Article 20, the right to self-determination has more detail than is found in common Article 1 of the UN Covenants on human rights (the International Covenant on Economic, Social and Cultural Rights and International Covenant on Civil and Political Rights). ${ }^{24}$ Article 20 stipulates:

1. All peoples shall have the right to existence. They shall have the unquestionable and inalienable right to self-determination. They shall freely determine their political

${ }^{18}$ American Declaration of the Rights and Duties of Man, May 2, 1948, 43 AJIL SUPP. 133 (1949). The conventions and other instruments of the Inter-American system are available at http://www1.umn.edu/humanrts/ iachr/iachr.html.

${ }^{19}$ American Convention on Human Rights, Nov. 22, 1969, 1144 UNTS 123.

${ }^{20}$ See Record of the Current Status of the Draft American Declaration on the Rights of Indigenous Peoples, Twelfth Meeting of Negotiations in the Quest for Points of Consensus (Washington, D.C., Nov. 30-Dec. 2, 2009), OAS Doc. GT/DADIN/doc.334/08 rev. 5 (Dec. 3, 2009) (draft Article 3).

${ }^{21}$ Convention for the Protection of Human Rights and Fundamental Freedoms, Nov. 4, 1950, ETS No. 5, 213 UNTS 221.

${ }^{22}$ African Charter on Human and Peoples' Rights, June 27, 1981, 21 ILM 58 (1982).

${ }^{23}$ In the preamble to the African Charter, the African states both reaffirm the pledge that they made in Article 2 of the OAU Charter, see infra note 31 , "to eradicate all forms of colonialism from Africa" and affirm that they are conscious "of their duty to achieve the total liberation of Africa" and to eliminate colonialism, neocolonialism, and apartheid. $I d$., pmbl., paras. 3,8 .

${ }^{24}$ Common Article 1 of the International Covenant on Economic, Social and Cultural Rights, Dec. 16, 1966, 993 UNTS 3 [hereinafter ICESCR], and International Covenant on Civil and Political Rights, Dec. 16, 1966, 999 UNTS 171 [hereinafter ICCPR], provides:

1. All peoples have the right of self-determination. By virtue of that right they freely determine their political status and freely pursue their economic, social and cultural development.

2. All peoples may, for their own ends, freely dispose of their natural wealth and resources without prejudice to any obligations arising out of international economic cooperation, based upon the principle of mutual benefit, and international law. In no case may a people be deprived of its own means of subsistence.

3. The States Parties to the present Covenant, including those having responsibility for the administration of Non-Self-Governing and Trust Territories, shall promote the realization of the right of self-determination, and shall respect that right, inconformity with the provisions of the Charter of the United Nations. 
status and shall pursue their economic and social development according to the policy they have freely chosen.

2. Colonized or oppressed peoples shall have the right to free themselves from the bonds of domination by resorting to any means recognized by the international community.

3. All peoples shall have the right to the assistance of the states parties to the present Charter in their liberation struggle against foreign domination, be it political, economic or cultural.

The article appears to recognize two distinct groups of peoples: those that are living under colonialism and oppression, and those that are not. The first group is entitled to independence and foreign assistance in the struggle for liberation (external self-determination). Other peoples are entitled to maintain their existence and exercise their self-determination, but within existing states.

Article 20 must be read in the context of the entire African Charter, whose very title indicates that it is concerned with collective peoples' rights as well as individual rights. Chapter 1 of the Charter, which expresses the guaranteed individual and collective rights, contains six separate articles on peoples' rights (Articles 19 to 24), beginning with the right of all peoples to be equal and to enjoy the same respect and the same rights. While such rights were included, the drafters of the Charter made a deliberate choice not to define "peoples." ${ }^{25}$ According to a present judge on the African Court, this decision indicated "the authors' intention not a priori to favor or exclude any interpretation of the word 'people," "26 which is in keeping with African Charter's clear concern to take account of the ethnic plurality of African states. ${ }^{27}$

Read in the light of the preamble to the African Charter, most of the articles on peoples' rights seem to apply broadly to indigenous and tribal groups within Africa that are not in colonial or oppressed states. The African Commission has so found in cases alleging violations of Article 19. While the applicants in these cases were unable to prove the alleged violations, the commission had no doubt that Article 19 applies to identifiable groups by reason of their common ancestry, ethnic origin, language, or cultural habits. ${ }^{28}$ The right of peoples to freely dispose of their wealth and natural resources, guaranteed in Article 21, has similarly been applied to identifiable groups within African states-for example, to the people of the Ogoni region of Nigeria. ${ }^{29}$

25 See Willem van Genugten, Protection of Indigenous Peoples on the African Continent: Concepts, Position Seeking, and the Interaction of Legal Systems, 104 AJIL 29, 38-43 (2010).

${ }^{26}$ FATSAH OUGUERGOUZ, THE AFRICAN CHARTER ON HUMAN AND PEOPLES' RIGHTS: A COMPREHENSIVE AGENDA FOR HUMAN DIGNITY AND SUSTAINABLE DEMOCRACY IN AFRICA 205 (2003).

${ }^{27}$ Id. at 209.

${ }^{28}$ See, for example, Legal Resources Foundation v. Zambia, Comm. No. 211/98, AFR. COMM'N ON HUM. 8 PEOPLES' RTS. [ACHPR], 14 ANN. ACTIVITY REP. (2000-01), and the series of cases against Mauritania, Malawi African Association v. Mauritania, Comm. No. 54/91, Amnesty International v. Mauritania, Comm, No.61/91, and Union Interafricaine des droits de l'bomme v. Mauritania, Comm. No. 98/93 (all in ACHPR, 13 ANN. ACTIVITY REP. (1999-2000)), in which the commission found some discriminatory practices against certain sectors of the Mauritanian population, but insufficient evidence to show domination of one section of the population against another. The commission's decisions are available at http://www.achpr.org/english/_info/List_Decision_Communications.html.

${ }^{29}$ Soc. \& Econ. Rts. Action Center v. Nigeria, Comm. No. 155/96, para. 58, ACHPR, 15 ANN. ACTIVITY REP. (2001-02), Annex V (reported by Dinah Shelton at 96 AJIL 937 (2002)). 
In keeping with the respect for ethnic and cultural diversity reflected in the preamble's reference to "the peoples of Africa," and in response to numerous inter-ethnic conflicts in African history, Article 20 begins with the right of peoples to existence. The right to existence is immediately followed by recognition of the right to self-determination, suggesting that all peoples entitled to existence are also entitled to self-determination, at least within the boundaries of existing states. ${ }^{30}$

Concern with limiting self-determination so as not to undermine territorial integrity was evident in the Charter of the Organization of African Unity, ${ }^{31}$ predecessor to the current African Union. The 1963 OAU Charter made a brief reference to the right of peoples to selfdetermination, proclaiming the "absolute dedication of the African rulers to the total emancipation of the African territories which are still dependent," ${ }^{32}$ while also asserting a commitment to the principle of territorial integrity through respecting colonial frontiers. ${ }^{33}$ In the 1986 ICJ judgment in Frontier Dispute (Burkina Fasov. Mali), the Court revealed its awareness of the problem of self-determination in the context of postcolonial Africa, but also referred to the importance of respecting colonial boundaries. ${ }^{34}$ Likewise, the 1999 Algiers Declaration adopted by the OAU Assembly of Heads of State and Government reaffirmed that respect for borders inherited at independence retains its "validity and permanence as a fundamental norm." 35

Several of those involved in the drafting of the African Charter ${ }^{36}$ later indicated that the inclusion of peoples' rights generally was related to enhancing the place of economic, social, and cultural rights in the text-a matter of considerable importance in Africa. Nonetheless, the Charter's drafters deliberately chose not to identify "people" for purposes of the collective rights guaranteed under Articles 19 to 24 and referred to in the title of the Charter. ${ }^{37}$ The African Commission also initially avoided defining the concept, in part due to the dearth of

${ }^{30}$ Section 235 ("Self-Determination") of the 1996 Constitution of South Africa makes this point clear in a national context: "The right of the South African people as a whole to self-determination, as manifested in this Constitution, does not preclude, within the framework of this right, recognition of the notion of the right of selfdetermination of any community sharing a common cultural and language heritage, within a territorial entity in the Republic or in any other way, determined by national legislation."

${ }^{31}$ OAU CHARTER, May 25, 1963, 2 ILM 766 (1963).

${ }^{32} I d$. . Art. 3(6).

${ }^{33}$ Id., Art. 3(3); see also Border Disputes Among African States, OAU Doc. AHG/Res. 16(I) (July 17-21, 1964), at http://www.africa-union.org/root/au/Documents/Decisions/hog/bHoGAssembly1964.pdf (reaffirming commitment to the principle of territorial integrity and respect for colonial frontiers).

34 "[T] he maintenance of the territorial status quo in Africa is often seen as the wisest course to preserve what has been achieved by peoples who have struggled for their independence, and to avoid a disruption which would deprive the continent of the gains achieved by much sacrifice. The essential requirement of stability in order to survive, to develop and gradually to consolidate their independence in all fields, has induced African States judiciously to consent to the respecting of colonial frontiers, and to take account of it in the interpretation of the principle of selfdetermination of peoples." Frontier Dispute (Burk. Faso/Mali), 1986 ICJ REP. 554, para. 25 (Dec. 22).

${ }^{35}$ Algiers Declaration, OAU Doc. AHG/Ded. 1 (XXXV), at 3 (July 12-14, 1999), at http://www.africa-union. $\mathrm{org} / \mathrm{root} / \mathrm{au} /$ Documents/Decisions/hog/9HoGAssembly1999.pdf.

${ }^{36}$ See Hassan B. Jallow, THE LAW OF THE AFriCAN (BANJul) Charter on Human and PEOPLE'S RIGHTS 28 (2007).

${ }^{37}$ See Report of the Rapporteur, OAU Ministerial Meeting on the Draft African Charter on Human and Peoples', Rights, OAU Doc. CAB/LEG/67/3/Draft Rapt. Rpt (II), at 4-5 (1980); see also N. A. M. Fanana, The Peoples' Rights Under the African Charter on Human and Peoples'Rights, 10 LESOTHO L.J. 48 (1997); Richard N. Kiwanuka, The Meaning of "People" in the African Charter on Human and Peoples' Rights, 82 AJIL 80 (1988). 
international jurisprudence and textual definition. ${ }^{38}$ Commentators have generally taken the view that the term "people" may be understood in several different ways, but that external selfdetermination should be limited to peoples under colonial or racial domination. ${ }^{39}$

\section{SECESSION Claims IN AFRICA}

The African Commission has considered several claims of external self-determination brought under the African Charter. In the first case, decided in 1995, the Katangese Peoples' Congress asked the commission to recognize the right to independence of Katanga. ${ }^{40}$ The commission declined to do so, with terse legal analysis. The commission noted that the applicants had complained only of a violation of Charter Article 20 (the right of self-determination), without indicating that other Charter rights were being violated. Considering that self-determination could be exercised not only by independence, but also "by self-government, local government, federalism, confederalism, unitarism or any form of relations that accords with the wishes of the people," 41 the commission held that it is only when the will of the people is denied, through a lack of ability to participate in government or due to massive human rights violations, that the principles of sovereignty and territorial integrity give way to self-determination through secession and independence. ${ }^{42}$ The decision thus seems to support "remedial secession," a highly contested notion during the Kosovo proceedings.

From the time that it was considering the Katangese Peoples' Congress case to the more recent complaint against Cameroon (decided in 2009; to be considered below), the commission focused its attention on "internal" self-determination, linking Charter Article 20 to Article 13 on the exercise of political rights. ${ }^{43}$ In a 1994 resolution on the military, ${ }^{44}$ the commission stated that any seizure of power by force constitutes a violation of both articles. Subsequent resolutions on specific coups have reiterated this position in stronger language, ${ }^{45}$ declaring military coups to be an intolerable infraction of democratic principles and the rule of law, and grave and unacceptable violations of Articles 13 and 20, as those articles guarantee the right of peoples to freely choose their government. Accordingly, in the context of complaints filed against Gambia following a military coup, the commission found that the forcible takeover of the

${ }^{38}$ REPORT OF THE AFRICAN COMMISSION'S WORKING GROUP OF EXPERTS ON INDIGENOUS POPULATIONS/COMMUNITIES 72-73 (2005), at http://www.achpr.org/english/Special\%20Mechanisms/Indegenous/ ACHPR\%20Report\%20ENG.pdf.

39 OUgUeRGOUZ, supra note 26, at 206, 253.

${ }^{40}$ Katangese Peoples' Congress v. Zaire, Comm. No. 75/92, ACHPR, 8 ANN. ACTIVITY REP. (1994-95).

${ }^{41} I d$., para. 4.

42 The commission seemed to suggest, $i d$, para. 6, that as long as everyone was being treated equally (poorly), no particular group had the right to escape:

In the absence of concrete evidence of violations of human rights to the point that the territorial integrity of Zaire should be called to question and in the absence of evidence that the people of Katanga are denied the right to participate in Government as guaranteed by Article 13(1) of the African Charter, the Commission holds the view that Katanga is obliged to exercise a variant of self-determination that is compatible with the sovereignty and territorial integrity of Zaire.

${ }^{43}$ Article 13 specifies: "Every citizen shall have the right to participate freely in the government of his country, either directly or through freely chosen representatives in accordance with the provisions of the law."

${ }^{44}$ Resolution on the Military, ACHPR Res. 10 (XVI) 94 (Nov. 3, 1994), in ACHPR, 8 ANN. ACTIVITY REP. (1994-95).

45 See, for example, the Resolutions on the Situation in Comoros, ACHPR Res. 34(XXV)99, and on the Situation in Niger, ACHPR Res. 35(XXV)99, in ACHPR, 12 ANN. ACTIVITY REP., Annex IV (1998-99). 
government was a "grave violation of the right of Gambian people to freely choose their government as entrenched in Article 20(1) of the Charter." ${ }^{\text {46 }}$

In a more recent major case on self-determination in the African system, the commission returned to the issue of secession and independence. In Kevin Mgwanga Gunme v. Cameroon, ${ }^{47}$ fourteen individuals on their own behalf and on behalf of the people of southern Cameroon ${ }^{48}$ complained that they had been deprived of the right of self-determination during the $1961 \mathrm{UN}$ plebiscite and in the subsequent federal constitution of Cameroon. They asserted that the people of southern Cameroon remain a separate and distinct people who have been marginalized, deprived of equal rights of representation in government, and denied the right to development. They also claimed that the government denied their right to education and discriminated against them in the legal system and in language rights. ${ }^{49}$ They alleged that a survey conducted in 1995 in southern Cameroon revealed that 99 percent of the people in that region favored full independence.

The Cameroon government contested jurisdiction, asserting that many of the acts complained of occurred before the Charter entered into force. ${ }^{50}$ It also challenged the existence of a territory known as "Southern Cameroon" and denied that southern Cameroonians constituted a people. After finding violations of many of the individual rights invoked by the petitioners, ${ }^{51}$ the commission addressed the collective rights invoked in the petition. The applicants were unstinting in labeling the control of southern Cameroon by the north a form of colonialism resulting from forcible and unlawful annexation. As the commission noted, these were "very serious allegations which go to the root of the statehood and sovereignty of the Republic of Cameroon." 52 The government submitted that the events that led to the creation of the state, including the 1961 UN plebiscite, were outside the competence of the

${ }^{46}$ Jawara v. Gambia, Comm. Nos. 147/95 \& 149/96, paras. 72-73, ACHPR, 13 ANN. ACTIVITY REP., Annex $\mathrm{V}(1999-2000)$.

${ }^{47}$ Kevin Mgwanga Gunmev. Cameroon, Comm. No. 266/2003, ACHPR, 26 ANN. ACTIVITY REP. (2008-09).

48 The African Charter allows the filing of an actio popularis. Id., para. 67; see Malawi African Ass'n v. Mauritania, Consolidated Comms. 54/91, 61/91, 98/93, 164/97-196/97, \& 210/98, ACHPR, 13 ANN. ACTIVITY REP., Appendix V (1999-2000).

${ }_{49}$ In all, the applicants claimed violations of African Charter Articles 2-6,7(1), 9-13, 17(1), 19-22, 23(1), 24, and 26.

${ }^{50}$ Malawi African Ass'n v. Mauritania, para. 91; Modise v. Botswana, Comm. No. 97/93, 14 ACHPR, 14 ANN. ACTIVITY REP. $(2000-01)$. On this issue, the commission agreed that some of the alleged violations occurred before the Charter entered into force, but noted that the effects continue to the present day and thus that the case was admissible. Kevin Mgwanga Gunme v. Cameroon, para. 96.

${ }^{51}$ Noting that English is one of the official languages of Cameroon, the commission found in Kevin Mgwanga Gunme v. Cameroon that the failure to register companies whose articles of association were in English constituted discrimination in violation of Charter Article 2. Likewise, the ratification of the treaty "Organisation pour l'harmonization des Droits d'Affaires en Afrique," which specified a preference for the French language, resulted in discrimination. The commission also found violations of the right to life, Article 4, as a result of the failure of the government to investigate and redress police killings of demonstrators; Article 5, torture; Article 6, prolonged arbitrary detention; Article 7, right to a fair trial, due to the transfer of prisoners to the north, trial before military tribunals, and failure to conduct the trials in a language that the defendants could understand; Article 10, right to association; Article 11, right to assembly; and Article 26, independence of the judicary. The commission did not find violations of Articles 3, 9, 12,13,17, or 19-24. Id., para. 214. As to Article 13, the right to participate in government, the commission held that the article guarantees participation, but not equal participation or representation, in government and the public administration. The facts showed such participation, with the consequence that no violation had occurred.

${ }^{52}$ Id., para. 153. 
commission, and the commission agreed. ${ }^{53}$ Thus, the commission could not pronounce on the applicants' allegations concerning "illegal and forced annexation, or colonial occupation of Southern Cameroon by the Respondent State." The commission could, however, examine issues of economic marginalization and denial of basic infrastructure as continuing violations, and held that the relocation of major economic projects and enterprises to the north constituted a violation of Charter Article 19, as it guarantees equality and equal rights between peoples.

Turning to the core of the complaint, the right of self-determination under Article 20, the applicants argued that the right of self-determination continues into the present because the results of the 1961 plebiscite were never submitted for approval by the parliament of Southern Cameroon before sovereignty was transferred to a single entity representing both sides. Thus, a condition for the validity of the plebiscite was never fulfilled. The government continued to contest the jurisdiction of the commission on this issue, but it also asserted that the southern Cameroonians do not constitute a "separate and distinct people" entitled to any form of selfdetermination. According to the government, the applicants were constructing their argument based on

the use of the English language (working language), the specificity of the legal system, of the educational system, of the system of government, traditional cultures. In fact, the specificities of former Southern Cameroons stem solely from the heritage of British administration and the legacy of Anglo-Saxon culture. No ethno-anthropological argument can be put forward to determine the existence of a people of Southern Cameroon, the Southern part being of the large Sawa cultural area, the northern part being part of the Grass fields' cultural area. ${ }^{54}$

The commission recognized the controversial nature of the issue of defining "peoples," noting the failure of the Charter and general international law to do so, but it recognized that "certain objective features attributable to a collective of individuals"55 may justify considering them a "people." Such recognition was important, in the commission's view, because the Charter makes peoples' rights equally important to individual rights; as such, they must be given protection. ${ }^{56}$ Each individual within a people is entitled to the enjoyment of all guaranteed individual rights but, in addition—as part of the collectivity - has common rights that benefit the community, such as the rights to development, to self-determination, and to an equitable share of the community's resources. ${ }^{57}$

To arrive at a definition of "people," the commission relied on, but did not consider itself bound by, the findings of a UNESCO group of experts convened to consider the concept of peoples' rights. ${ }^{58}$ The UNESCO group concluded that a group could be considered a people

${ }^{53}$ The UN plebiscite went to the heart of the complaint because the applicants asserted that southern Cameroonians were given only two options: merger with francophone northern Cameroon or merger with Nigeria. Independence was not a choice presented to them. Id., paras. 2-4.

${ }^{54} I d$, para. 168.

s5 Id., para. 169.

${ }^{56} I d$. , para. 176.

${ }^{57} \mathrm{Id}$.

${ }^{58}$ See Final Report and Recommendations, International Meeting of Experts on Further Study of the Concept of the Rights of Peoples, UNESCO Doc, SHS-89/CONF.602/7 (1990). 
if it shared some of the following characteristics: a common historical tradition, a racial or ethnic identity, cultural homogeneity, linguistic unity, religious and ideological affinities, territorial connection, and a common economic life. ${ }^{59}$ Moreover, a people can be self-identified by their common consciousness of constituting a people. Thus, for the commission, the collective rights in the Charter can be exercised by a people bound together by their history and traditions, as well as by their racial, ethnic, cultural, linguistic, religious, ideological, geographical, economic, or other bonds.

Applying these criteria, the commission concluded that the southern Cameroonians can legitimately claim to be a people with a distinct identity that attracts certain collective rights. In contrast to the government, the commission did not find that ethno-anthropological attributes are determinative- except in the case of indigenous peoples. Indeed, according to the commission, the guarantee of equal protection to peoples (Article 19) includes those whose roots are not African. What the people of the southern Cameroon share is a common history, linguistic tradition, territorial connection, and political outlook. "More importantly, they identify themselves as a people with a separate and distinct identity." ${ }^{60}$ This innate characteristic should be recognized by those external to the group. ${ }^{61}$

The commission thus gave a very broad reading to the term "people"- one that can potentially apply not only to indigenous and tribal peoples, but also to other groups within African societies, including the descendants of European colonial settlers, Asian immigrant communities, and nomadic societies. If all the collective rights in the Charter adhere to all of these groups, two alternatives may result. The pessimistic view is that the recognition and exercise of self-determination by African peoples could further weaken the fragile condition of many African states, bringing about their fragmentation and disintegration. The contrasting, optimistic assessment considers that recognizing the rights of Africa's many peoples could lead to more democratic, decentralized governments, thereby enhancing local decision making and respect for human rights within existing states, and strengthening them in the long run.

Turning to the exercise of the right of self-determination in the Cameroon case, the commission considered the events in southern Cameroon only after the entry into force of the African Human Rights Charter-in particular, from the constitutional conferences of 1993 and 1994 and the signature referendum on independence of 1995 . The complainants insisted on their right to self-determination, which the government, in turn, characterized as a secessionist agenda.

The commission reaffirmed that it is obligated to uphold the territorial integrity of states in the African system and thus it that could not "envisage, condone or encourage secession," 62 but it reiterated that the right of self-determination can be accomplished by autonomy within a sovereign state, in the context of self-government, confederacy, or federation. It also noted that the Cameroon government had implicitly accepted that the right of self-determination may be triggered in cases of massive violations of human rights or the denial of participation in public

${ }^{59} I d$., para. 22.

${ }^{60}$ Kevin Mgwanga Gunme v. Cameroon, para. 179.

61 The commission candidly recognized that postcolonial Africa has not been free of domination and ethnic conflict, although it does not constitute colonialism "in the classic sense." Id., para. 181. The commission found that the solution to such problems lies in recognition of the claims of subordinate groups, like those involved in the present case, and in the good faith participation in regional dispute settlement mechanisms like the commission's complaint procedure. See, e.g., id., paras. 181, 199.

${ }^{62} \mathrm{Id}$., para. 190. 
affairs, ${ }^{63}$ both of which were alleged by the complainants. Given that the commission had already found violations of Charter Articles 2, 4, 5, 6,7,11, and 19, the question was whether the violations were so serious as to call into question the territorial integrity of the state. The commission found the answer in its conclusion that the state had not violated Article 13, because the evidence demonstrated that the people of southern Cameroon are represented in the National Assembly (even though as part of an opposition party). In other words, the conditions required by Charter Article 20(2) _oppression and domination-had not been met to the extent warranting invocation of the right to self-determination through secession and independence. ${ }^{64}$ In conclusion, the commission urged the state to address the grievances and violations of the rights of the southern Cameroonians through its democratic institutions. ${ }^{65}$

The commission's conclusion is consistent with the long-standing preference afforded the principle of territorial integrity in Africa. Article 13 of the Charter appears to play an especially significant role in deciding whether a people is so oppressed or excluded that it is entitled to declare independence and form its own government. The commission seems to believe that so long as the various peoples in a state have the ability to participate in government through democratic institutions - even in a disfavored, minority role-they have the potential to prevent human rights violations and ensure that any violations that do occur are redressed. The lengthy list of violations found in this case, however, suggests that the commission is perhaps too optimistic about the ability of a dominated minority to enjoy the rights to which it is entitled under the Charter. The commission recommended that the parties engage in a constructive dialogue and resolve the outstanding issues within six months. The expiration of the period did not produce a resolution, and the groups that brought the petition continue to press for independence from the north.

The same commission session that concluded the case against Cameroon elaborated further on the concept of "peoples" in joined cases against Sudan. ${ }^{66}$ The petitioners alleged violations of numerous individual rights and also the collective right to development guaranteed in Charter Article 22, ${ }^{67}$ The latter required the commission to determine whether the victims constituted a "people." The commission cited the same factors identified in the Cameroon case to interpret the content of the term but added that "in States with mixed racial composition, race

\section{${ }^{63} \mathrm{Id}$.}

${ }^{64}$ In this respect the African Commission's opinion tracks much of the work of the United Nations, which defined the right of self-determination in the context of foreign subjugation, domination, or exploitation in the Declaration on the Granting of Independence to Colonial Countries and Peoples, GA Res. 1514 (XV) (Dec. 14, 1960). The General Assembly also affirmed the obligation of states to transmit information to the committee on non-self-governing territories if the territory "is geographically separate and is distinct ethnically and/or culturally from the country administering it." Id., Princ. IV.

65 The commission's specific recommendations were that the state abolish discriminatory linguistic practices in business and the judiciary, locate national projects equitably throughout the country, compensate companies discriminated against, engage in a constructive dialogue to resolve the constitutional issues, and reform the judicial council. Unusually, it also addressed recommendations to the complainants, including that they transform themselves into political parties, abandon secession efforts, and engage in constructive dialogue with the government.

${ }^{66}$ The joined cases were Sudan Human Rights Organisation v. Sudan, Comm. No. 279/03, and Centeron Housing Rights and Evictions v. Sudan, Comm. No. 296/05, in ACHPR, 28 ANN. ACTIVITY REP. (2009-10) [hereinafter Sudan cases].

${ }^{67}$ Article 22 provides: "1. All peoples shall have the right to their economic, social and cultural development with due regard to their freedom and identity and in the equal enjoyment of the common hetitage of mankind. 2. States shall have the duty, individually or collectively, to ensure the exercise of the right to development." 
becomes a determinant of groups of 'peoples', just as ethnic identity can also be a factor." 68 While acknowledging that the history of colonial and apartheid rule made reference to race difficult, the commission stated its belief that "racial and ethnic diversity on the continent contributes to the rich cultural diversity which is a cause for celebration." ${ }^{69}$ In the context of that diversity, the commission proceeded to articulate the rights of indigenous peoples and communities in Africa and how to protect them against both external and internal abuse.

Addressing violations committed against the people of Darfur, the commission found that they constitute a people for purposes of Article 19. As such, "They do not deserve to be dominated by a people of another race in the same state." ${ }^{" 70}$ The military campaign against the people of Darfur constituted "a massive violation" of individual and collective rights, including Article 22. The applicants did not invoke the right of self-determination in their complaints, and the commission did not address the topic, perhaps because the Comprehensive Peace Agreement made it unnecessary as it explicitly allows a referendum on secession. However, had the commission applied the test that it set forth in its earlier decisions, it might well have found that in the case of Sudan, the level of oppression and the massive human rights violations justified secession and independence for Darfur.

\section{SPECIAL INTERNAL SELF-DETERMINATION FOR INDIGENOUS AND TRIBAL PEOPLES}

Global and regional human rights law has evolved a set of special norms concerning indigenous and tribal peoples. These norms have been elaborated on, and applied by, the InterAmerican Commission and Court on Human Rights, as well as the African Commission on Human and Peoples' Rights, to ensure the internal self-determination of indigenous and tribal peoples. After a brief overview of the relevant UN instruments, this part will look at the InterAmerican case law $^{71}$ and then at the African Commission's recent case involving Kenya, ${ }^{72}$ which specifically relied on the Inter-American jurisprudence.

\section{UNInstruments}

While no general international human rights treaty mentions indigenous peoples, the International Covenant on Civil and Political Rights has two relevant provisions (Articles 1 and 27), ${ }^{73}$ and the definition of racial discrimination in the Convention on the Elimination of

\footnotetext{
${ }^{68}$ Sudan cases, supra note 66 , para. 220.

${ }^{69}$ Id., para. 221.

${ }^{70} \mathrm{Id}$., para. 223.

${ }^{71}$ See infra notes 79-94 and accompanying text.

${ }^{72}$ See infra notes 95-103 and accompanying text.

${ }^{73}$ ICCPR Article 1 provides:
}

1. All peoples have the right of self-determination. By virtue of that right they freely determine their political status and freely pursue their economic, social and cultural development.

2. All peoples may, for their own ends, freely dispose of their natural wealth and resources without prejudice to any obligations arising out of international economic co-operation, based upon the principle of mutual benefit, and international law. In no case may a people be deprived of its own means of subsistence. 
All Forms of Racial Discrimination is broad enough to include indigenous peoples. ${ }^{74} \mathrm{After}$ surviving five hundred years of conquest, marginalization, and genocidal policies, indigenous peoples throughout the world have sought specific instruments recognizing their right of selfdetermination and their unique status in international law. ${ }^{75}$

During the decades-long negotiations for the UN Declaration on the Rights of Indigenous Peoples, indigenous representatives pressed for recognition of the right of self-determination, calling it "the heart and soul of the declaration."76 They ultimately succeeded, with Articles 3

3. The States Parties to the present Covenant, including those having responsibility for the administration of Non-Self-Governing and Trust Territories, shall promote the realization of the right of self-determination, and shall respect that right, in conformity with the provisions of the Charter of the United Nations.

Article 27 provides:

In those States in which ethnic, religious or linguistic minorities exist, persons belonging to such minorities shall not be denied the right, in community with the other members of their group, to enjoy their own culture, to profess and practise their own religion, or to use their own language.

The efforts of indigenous peoples to invoke ICCPR Article 1 through complaints brought under the treaty's Optional Protocol have been unsuccessful because the Human Rights Committee considers that its jurisdiction is limited to individual rights to the exclusion of collective rights of peoples. Lubicon Lake Band v. Canada, Comm. No. 167(1984, UN Doc. CCPR/C/38/D/167/1984 (Mar. 26, 1990).

The Committee explained its views in General Comment No. 23, The Rights of Minorities, para. 3.1, UN Doc. CCPR/C/21/rev.1/Add.5 (1994):

The Covenant draws a distinction between the right to self-determination and the rights protected under article 27. The former is expressed to be a right belonging to peoples and is dealt with in a separate part (Part I) of the Covenant. Self-determination is not a right cognizable under the Optional Protocol. Article 27, on the other hand, relates to rights conferred on individuals as such and is included, like the articles relating to other personal rights coferred on individuals, in Part III of the Covenant and is cognizable under the Optional Protocol.

See also Human Rights Committee, General Comment No. 12, Right to Self-Determination of Peoples (Mar. 13, 1984), reprinted in UN Doc. HRI/GEN/1/Rev.9 (Vol. I), at 183 (2008).

${ }^{74}$ See Committee on the Elimination of Racial Discrimination, General Recommendation No. 23, supra note 17, para. 4 (calling on states to take certain measures to recognize and ensure the rights of indigenous peoples); see also Committee on the Elimination of Racial Discrimination, General Recommendation No. 21, Right of SelfDetermination, Report of the Commitree on the Elimination of Racial Discrimination, UN GAOR, 51 st Sess., Supp. No. 18, Annex V, UN Doc. A/51/18 (Mar. 8, 1996), calling the right to self-determination of peoples "a fundamental principle of international law" having an internal aspect that permits all peoples to pursue freely their economic, social, and cultural development and to participate in the conduct of public affairs, and an external aspect that involves each people determining its political status. Id., paras. 1, 4. The committee cautioned, however, that "international law has not recognized a general right of peoples unilaterally to declare secession from a State." Id., para. 6.

75 See S. JAMES ANAYA, INDIGENOUS PEOPLES IN INTERNATIONAL LAW (2d ed. 2004); S. James Anaya $\&$ Robert A Williams Jr., The Protection of Indigenous Peoples' Rights over Lands and Natural Resources Under the InterAmerican Human Rights System, 14 HARV. HUM. RTS. J. 33 (2001); PATRICK THORNBERRY, INDIGENOUS PEOPLES AND HUMAN RIGHTS (2002); Robert K. Hitchcock, International Human Rights, the Environment, and Indigenous Peoples, 5 COLO. J. INT'L ENVTL. L. \& POL'Y 1 (1994); William Andrew Shutkin, Note, International Human Rights Law and the Earth: The Protection of Indigenous Peoples and the Environment, 31 VA. J. INT'L L. 479 (1991); Lee Swepston, A New Step in the International Law on Indigenous and Tribal Peoples: ILO Convention 169 of 1989, 15 OKLA. CITY U. L. REV. 677 (1990); Mario Ibarra, Traditional Practices in Respect of the Sustainable and Environmentally Sound Self-Development of Indigenous People, UN Doc. E/CN.4/Sub.2/1992/31/Add.1 (May 1, 1992); Siegfried Wiessner, Rights and Status of Indigenous Peoples: A Global Comparative and International Legal Analysis, 12 HARV. HUM. RTS. J. 57 (1999).

${ }^{76}$ Quoted in INDIGENOUS PEOPLE, THE UNITED NATIONS AND HUMAN RIGHTS 46 (Sarah Pritchard ed., 1998). 
and 4 of the Declaration specifying a right of (internal) self-determination. ${ }^{77}$ In addition, various provisions include rights of consultation, to public participation, and, in particular, to ancestral lands, territories, and resources. ${ }^{78}$ The UN special rapporteur on the situation of human rights and fundamental freedoms of indigenous peoples has also spoken out on the right to self-determination of indigenous peoples ${ }^{79}$-in particular, the right to participate in decision making and to be consulted on decisions affecting them.

None of the indigenous cases brought to regional human rights bodies thus far has claimed a right to an independent state. Instead, indigenous peoples have demanded recognition and titling of their ancestral lands and the right to decide on the scope and nature of development projects that affect their lands and resources-in particular, infrastructure projects and extractive industries. The nature of the claims has not made the cases any easier or the governments any less concerned to limit the indigenous right of self-determination. Indeed, many countries have strongly resisted indigenous claims because indigenous lands and resources are seen as a major source of minerals, hydroelectric power, and ecotourism income that can augment the development of the state, even at the cost of decimating or eliminating indigenous communities.

\section{Inter-American Jurisprudence}

The views of the Inter-American Commission on Human Rights have evolved considerably on the issue of the rights of indigenous peoples. In 1983, in its report on the Miskito people of Nicaragua, the commission observed:

The present status of international law does recognize observance of the principle of selfdetermination of peoples, which it considers to be the right of a people to independently choose their form of political organization and to freely establish the means it deems appropriate to bring about their economic, social and cultural development. This does not

77 The declaration, supra note 13, provides as follows:

Article 3. Indigenous peoples have the right to self-determination. By virtue of that right they freely determine their political status and freely pursue their economic, social and cultural development.

Article 4. Indigenous peoples, in exercising their right to self-determination, have the right to autonomy or self-government in matters relating to their internal and local affairs, as well as ways and means for financing their autonomous functions.

${ }^{78}$ Declaration Article 26 provides:

1. Indigenous peoples have the right to the lands, territories and resources which they have traditionally owned, occupied or otherwise used or acquired.

2. Indigenous peoples have the right to own, use, develop and control the lands, territories and resources that they possess by reason of traditional ownership or other traditional occupation or use, as well as those which they have otherwise acquired.

3. States shall give legal recognition and protection to these lands, territories and resources. Such recognition shall be conducted with due respect to the customs, traditions and land tenure systems of the indigenous peoples concerned.

${ }^{79}$ Special Rapporteur on the Situation of Human Rights and Fundamental Freedoms of Indigenous People, S. James Anaya, Report on the Situation of Indigenous Peoples in Nepal, paras. 62-69, UN Doc. A/HRC/12/34/ Add. 3 (2009). 
mean, however, that it recognizes the right to self-determination of any ethnic group as such. $^{80}$

The commission concluded that no right of self-determination applied to the Miskitos. ${ }^{81}$

Although the Inter-American Commission and Court on Human Rights have primarily assessed indigenous land claims under the right to property, ${ }^{82}$ they have begun to refer to the right of self-determination in the context of land and resource claims. In its 1997 report on the human rights situation in Ecuador, the commission affirmed the right of states to economic development, including the freedom to exploit their natural resources through the granting concessions and acceptance of international investment, but such activities must be conducted consistent with human rights. In the report, the commission criticized the absence or inappropriateness of regulation and the lack of supervision in applying extant norms, which translated into violations of human rights protected by the American Convention. ${ }^{83}$

In the first case on indigenous land and resource rights to reach the Inter-American Court, the Awas Tingni case, ${ }^{84}$ the court insisted that Article 21 of the American Convention protects the right to property in a sense that encompasses the rights of members of indigenous communities to their communal property. ${ }^{85}$ The Court held:

Indigenous groups, by the fact of their very existence, have the right to live freely in their own territory; the close ties of indigenous people with the land must be recognized and understood as the fundamental basis of their cultures, their spiritual life, their integrity, and their economic survival. For indigenous communities, relations to the land are not merely a matter of possession and production but a material and spiritual element which they must fully enjoy, even to preserve their cultural legacy and transmit it to future generations. ${ }^{86}$

Based on this understanding, the Court considered that Nicaragua had violated the rights of the Awas Tingni and ordered the state to delimit, demarcate, and title the territory belonging to the community. Until then, the state was required to abstain from carrying out "actions that might lead the agents of the State itself, or third parties acting with its acquiescence or its tolerance, to affect the existence, value, use or enjoyment of the property located in the geographical area where the members of the Community live and carry out their activities." 87

New indigenous land and resource claims were brought to the Inter-American Commission and Court following the Awas Tingni decision. First, the Court decided the case of the

${ }^{80}$ Inter-Am. Comm'n on Hum. Rts., Report on the Situation of a Segment of the Nicaraguan Population of Miskito Origin, OAS Dec. OEA/Ser.L/V.II.62, doc. 10 rev. 3, pt. IIB, para. 9. (1983). Materials from the commission are available at http://www1.umn.edu/humanrts/iachr/iachr-index.html.

${ }^{81} I d$, para. 11.

${ }^{82}$ Article 21 of the American Convention, supra note 19, establishes that "everyone has the right to the use and enjoyment of his property."

${ }^{83}$ Inter-Am. Comm'n on Hum. Rts., Report on the Situation of Human Rights in Ecuador, OAS Doc. OEA/ Ser.L/V/II.96, doc. 10 rev. 1 (1997).

${ }^{84}$ Mayagna (Sumo) Awas Tingni Cmty. v. Nicaragua, 2001 Inter-Am. Ct. H.R. (ser. C) No. 79 (Aug. 31, 2001).

The decisions of the Court are available at http:/wwwl.umn.edu/humanrts/iachr/iachr.html.

${ }^{85} \mathrm{Id}$., para. 148.

${ }^{86}$ Id., para. 149.

${ }^{87}$ Id., para. 153. On December 18, 2008, the Court reported compliance with the Awas Tingni judgment. 
Indigenous Community Yakye Axa v. Paraguay. ${ }^{88}$ Nine months later, Sawhoyamaxa Indigenous Community v. Paraguay ${ }^{89}$ addressed the difficult issue of returning indigenous lands after they had been sold to, and occupied by, others. The Court summed up its earlier jurisprudence: (1) traditional possession of their lands by indigenous people has equivalent effects to those of a state-granted full property title; (2) traditional possession entitles indigenous people to demand official recognition and registration of property title; (3) the members of indigenous peoples who have unwillingly left or loss possession of their traditional lands maintain property rights thereto, even though they lack legal title, unless the lands have been lawfully transferred to third parties in good faith; and (4) the members of indigenous peoples who have unwillingly lost possession of their lands, when those lands have been lawfully transferred to innocent third parties, are entitled to restitution or to obtain other land of equal extension and quality. Consequently, possession is not a requisite conditioning the existence of indigenous land restitution rights.

In Saramaka People v. Suriname ${ }^{90}$ the Inter-American Court referred for the first time to the right of self-determination in interpreting indigenous land and resource rights under Convention Article 21. It affirmed that Article 21 must be interpreted in light of domestic legislation pertaining to indigenous peoples' rights and must also take into account ILO Convention No. 169. The Court noted that the Committee on Economic, Social and Cultural Rights ${ }^{91}$ has interpreted common Article 1 of the UN Covenants as being applicable to indigenous peoples. ${ }^{92}$ Accordingly, by virtue of the right of indigenous peoples to self-determination recognized under said Article 1, they may "freely pursue their economic, social and cultural development" and may "freely dispose of their natural wealth and resources" so as not to be "deprived of [their] own means of subsistence." ${ }^{93}$ The Court considered that the rules of interpretation contained in Article 29(b) of the American Convention precluded it from interpreting Convention Article 21 "in a manner that restricts its enjoyment and exercise to a lesser degree than what is recognized"94 in the UN Covenants. Accordingly, the Court concluded that Convention Article 21 calls for the right of members of indigenous and tribal communities to freely determine and enjoy their own social, cultural, and economic development, which includes the right to enjoy their particular spiritual relationship with the territory that they have traditionally used and occupied. As a corollary, the state has an obligation to adopt special measures to recognize, respect, protect, and guarantee the communal property right of the members of indigenous and tribal communities to such territory.

As for the resource rights accompanying ownership of the land, the Court recalled its jurisprudence as stated in the Yakye Axa and Sawhoyamaxa cases: for the same reasons that members

\footnotetext{
${ }^{88}$ Yakye Axa Indigenous Cmty. v. Paraguay, 2005 Inter-Am. Ct. H.R. (ser. C) No. 125 (June 17, 2005).

${ }^{89}$ Sawhoyamaxa Indigenous Cmty v. Paraguay, 2006 Inter-Am. Ct. H.R. (ser. C) No. 146 (Mar. 29, 2006).

${ }^{90}$ Saramaka People v. Suriname, Preliminary Objections, Merits, Reparations, and Costs, 2007 Inter-Am. Ct. H.R. (ser. C) No. 172 (Nov. 28, 2007) (reported by Marcos Orellana at 102 AJIL 841 (2008)).

91 The Committee on Economic, Social and Cultural Rights monitors compliance with the ICESCR, supra note

${ }^{22}$ See Committee on Economic, Social and Cultural Rights, Consideration of Reports Submitted by States Parties Under Articles 16 and 17 of the Covenant, Concluding Observations on Russian Federation, para. 11 (Dec. 12, 2003), UN Doc. E/C.12/1/Add.94 (expressing the committee's concern for the "precarious situation of indigenous communities in the State party, affecting their right to self-determination under article 1 of the Covenant").

${ }^{93}$ ICESCR, supra note 24, Art. 1.

${ }^{94}$ Saramaka People v. Suriname, para. 93.
} 24. 
of tribal and indigenous communities have a right own the lands that they have traditionally used and occupied for centuries, they have the right to own the natural resources that they have traditionally used within their territory. Without these entitlements and the associated lands and natural resources, the very physical and cultural survival of such peoples is in peril. That is, the aim and purpose of the special measures required on behalf of the members of indigenous and tribal communities is to guarantee that they may continue living their traditional way of life and that their distinct cultural identity, social structure, economic system, customs, beliefs, and traditions are respected, guaranteed, and protected by states. The demand for collective land ownership by members of indigenous and tribal peoples thus derives from the need to ensure the security and permanence of their control and use of the natural resources-which, in turn, maintains their very way of life. This connectedness between the territory and the natural resources necessary for their physical and cultural survival is precisely what needs to be protected under Article 21 of the American Convention in order to guarantee the members of indigenous and tribal communities' right to the use and enjoyment of their property.

From this analysis, the Court inferred that the natural resources found in and within indigenous and tribal people's territories that are protected under Article 21 are those natural resources traditionally used and necessary for the very survival, development, and continuation of such people's way of life. Thus, in accordance with Convention Article 1(1), in order to guarantee that issuing concessions within the territory of an indigenous people and thereby restricting the property rights of its members does not amount to a denial of their survival as a tribal people, the State must abide by three safeguards: first, the state must ensure the effective participation of the members of the people, in conformity with their customs and traditions, regarding any development, investment, exploration, or extraction plan within the ancestral territory; second, the state must guarantee that they will receive a reasonable benefit from any such plan within their territory; and third, the state must ensure that no concession will be issued within the territory unless and until independent and technically capable entities, with the state's supervision, perform a prior environmental and social impact assessment. These safeguards are intended to preserve, protect, and guarantee the special relationship that the members of an indigenous or tribal people have with their territory-which, in turn, ensures their survival as a community. Additionally, and critically, the Court considered that, regarding large-scale development or investment projects that would have a major impact within indigenous ancestral lands, the state has a duty not only to consult with members of the indigenous people, but also to obtain their free, prior, and informed consent, according to their customs and traditions.

As the above cases indicate, the Inter-American Court, by grounding its decisions in American Convention Article 21, has only recently begun to address self-determination, a right not explicitly guaranteed in the American human rights instruments. The issue of self-determination is presented more clearly in the African context, where the African Commission can apply the collective rights contained in the African Charter, including the right to self-determination. The Inter-American Court has moved closer to the approach of the African Commission by relying on developments in human rights law at the global level. These developments are critical because Article 21 guarantees the right to property, but it also makes clear that the right is a limited one. The second and third paragraphs of Article 21 set forth the conditions under which the right may be restricted or even 
extinguished. First, Article 21(b) provides that the use and enjoyment of property can be subordinated, by law, to "social interest." Second, Article 21(c) adds that a person may be deprived of his or her property, by law, for reasons of public utility or social interest, provided just compensation is paid.

These limits on the right to property are especially important in relation to resource rights on indigenous lands because governments routinely claim that a public interest in economic development overrides indigenous property rights. Only by interpreting Article 21 through the lens of ILO Convention No. 169 and the UN Declaration on the Rights of Indigenous Peoples have the inter-American institutions arrived at the concept of sui generis obligations owed to indigenous peoples, as reflected in the Court's case law. ${ }^{95}$ As the Saramaka People case makes clear, these obligations do not preclude all infrastructure and extractive industry projects on indigenous lands, but they do require that specific legal processes be followed, that mitigation and benefit-sharing measures be established, and, in some circumstances, that the indigenous group be allowed to say no.

\section{Self-Determination for African Indigenous Peoples}

In 2009, the African Commission addressed for the first time the rights of indigenous peoples. ${ }^{96}$ The complaint on behalf of the Endorois community alleged that Kenya had forcibly removed the Endorois from their ancestral lands without proper prior consultations or adequate and effective compensation when the government created the Lake Hannington Game Reserve in 1973 and re-gazetted the Lake Bogoria Game Reserve in 1978 (together, the Game Reserve) - with the consequence that they were evicted from their ancestral lands. After domestic litigation failed to provide redress in 2000, additional parts of the Endorois' ancestral lands were allegedly demarcated and sold by the state to third parties. In 2002, concessions for ruby mining on the Endorois' lands were granted to a private company. The petitioners further alleged that the process of evicting them from their ancestral lands severed their spiritual, cultural, and economic ties to the land. In sum, the complaint asserted that in the creating and maintaining the Game Reserve, the government disregarded national law, Kenyan constitutional provisions, and rights guaranteed in the African Charter, including the rights to property, to free disposition of natural resources, to religion, to cultural life, and to develop as a people. The Endorois sought restitution of their land, with legal title, clear demarcation, and compensation to the community for all their losses.

The government disputed the characterization of the Endorois as a community/subtribe or clan on their own. In response, the African Commission noted that while the terms "peoples" and "indigenous community" arouse emotive debates, the commission through its Working

${ }^{95}$ See, e.g., Mayagna (Sumo) Awas Tingni Cmty. v. Nicaragua, supra note 84, para. 148 (noting "[t]hrough an evolutionary interpretation of international instruments for the protection of human rights, taking into account applicable norms of interpretation and pursuant to article 29 (b) of the Convention-which precludes a restrictive interpretation of rights-, it is the opinion of this Court that article 21 of the Convention protects the right to property in a sense which includes, among others, the rights of members of the indigenous communities within the framework of communal property").

${ }_{96}^{6}$ Centre for Minority Rts. Dev. (Kenya) v. Kenya, Comm. No. 276/2003 (Afr. Comm'n on Hum. \& Peoples' Rts. Feb. 4, 2010). 
Group of Experts on Indigenous Populations/Communities had set out four criteria for identifying indigenous peoples: ${ }^{97}$ (1) the occupation and use of a specific territory, (2) the voluntary perpetuation of cultural distinctiveness, (3) self-identification as a distinct collectivity, as well as recognition by other groups, and (4) an experience of subjugation, marginalization, dispossession, exclusion, or discrimination. After studying all the submissions of the complainants and the respondent state, the African Commission concluded that the Endorois culture, religion, and traditional way of life are intimately intertwined with their ancestral lands, that Lake Bogoria and the Monchongoi Forest are central to the Endorois' way of life, and that without access to their ancestral lands, the Endorois are unable to exercise fully their cultural and religious rights, and feel disconnected from their lands and ancestors.

On the merits of the complaint, Kenya conceded that the Endorois had been removed from their ancestral lands, but argued that it was for a legitimate public purpose. The African Commission agreed that in some situations it may be necessary to place some form of limited restrictions on a right protected by the African Charter. Nevertheless, the commission noted that the raison d'être for an especially harsh limitation, such as the one experienced by the Endorois, must be based on compelling reasons and that the respondent state must prove such interference to be not only proportionate to a specific need, but also reasonable. It was not convinced that removing the Endorois from their ancestral lands was a lawful action in pursuit of economic development or ecological protection. In the commission's view, allowing the Endorois to use the land to practice their religion would not detract from the goal of conservation or of developing the area for economic reasons. ${ }^{98}$

Concerning the right to property, the African Commission decided that the first step in protecting traditional A frican communities was to acknowledge that such communities' rights and interests in, and benefits from, their traditional lands constitute "property" under the African Charter and that special measures may be needed to secure these "property rights." Thus, although the Endorois did not have registered property, they cultivated ancestral lands and lived in houses built on it. The commission further noted that the applicants had unchallenged rights over the common land in the village, such as the pasture, grazing, and forest land, and that they earned their living from stockbreeding and tree felling. The commission concluded that the Endorois property rights were encroached upon-in particular, by the expropriation and the effective denial of ownership of their land.

It agrees with the Complainants that the Endorois were never given the full title to the land they had in practice before the British colonial administration. Their land was instead made subject to a trust, which gave them beneficial title, but denied them actual title. The African Commission further agrees that ... the trust land system has proved inadequate to protect their rights. ${ }^{99}$

Related to the land claims, the complainants alleged that their right to development as a people under Charter Article 21 had been violated because the Endorois community had been unable to access the vital resources in the Lake Bogoria region since their eviction from the Game Reserve. The respondent state denied the allegation and asserted that the Endorois had

\footnotetext{
${ }^{77}$ REPORT OF THE AFRICAN COMMISSION'S WORKING GROUP OF EXPERTS ON INDIGENOUS POPULATIONS/COMMUNITIES, supra note 38.

${ }^{98}$ Centre for Minority Rts. Dev. (Kenya) v. Kenya, para. 173.

${ }^{99}$ Id., para. 199.
} 
immensely benefited from the tourism and mineral prospecting activities and that they had been consulted. Although the commission and the Endorois agreed that proceeds from the Game Reserve had been used to finance projects useful to the Endorois, the commission found that these measures were insufficient to preserve the Endorois' rights under the Charter.

The commission acknowledged the jurisprudence of the Inter-American Court but also noted that the American Convention does not have an equivalent of the African Charter's Article 21 on the right to natural resources and that the Court therefore read the right to natural resources into the right to property (Article 21 of the American Convention), with the consequence that it saw the limitations on the right to property as likewise applying to natural resources. The African Commission found that applying the same " 'test' in both cases makes for a much higher threshold when potential spoliation or development of the land is affecting indigenous land." 100 The commission noted that in the African context, the right to the natural resources contained within their traditional lands vested in the indigenous people. Earlier jurisprudence made clear that a people inhabiting a specific region within a state can claim the protection of Article $21^{101}$ and that their rights could be limited only according to Article 14 of the African Charter. That article establishes a two-pronged test that the limitation be "in the interest of public need or in the general interest of the community" and "in accordance with appropriate laws." In addition, a government must consult with indigenous peoples, especially when dealing with sensitive issues such as land. ${ }^{102}$ With regard to the Endorois, the commission found that the consultations were inadequate and could not be considered effective participation. Community members had been informed of the impending establishment of the Game Reserve as a fait accompli and had not given an opportunity to shape the policies of, or their role in, the Game Reserve. In particular, the state did not obtain the prior, informed consent of the Endorois before designating their land as a Game Reserve and commencing their eviction, and it failed to communicate effectively to the Endorois that they would be denied all rights of return to their lands, including unfettered access to grazing land and the medicinal salt licks for their cattle.

The African Commission went further than the Inter-American Court in holding that "any development or investment projects that would have a major impact within the Endorois territory, the State has a duty not only to consult with the community, but also to obtain their free, prior, and informed consent, according to their customs and traditions." ${ }^{103}$ The InterAmerican Court, as noted above, had limited the prior, informed consent requirement to those major projects that would threaten the very existence or way of life of the indigenous community.

Finally, in relation to benefit sharing, the African Commission held that the right to development will be violated when the development in question decreases the well-being of the community. Failure to duly compensate (even if the other criteria of legitimate aim and proportionality are satisfied) result in a violation of the right to property. The African Commission

${ }^{100}$ Id., para. 266.

${ }^{101}$ Id., para. 274 (citing Soc. \& Econ. Rts. Action Center v. Nigeria, supra note 29, paras. 56-58).

102 REPORT OF THE AFRICAN COMMISSION'S WORKING GROUP OF EXPERTS ON INDIGENOUS POPULATIONS/COMMUNITIES, supra note 38; see also ILO Convention No. 169, supra note 12 ("Consultations carried out in application of this Convention shall be undertaken, in good faith and in a form appropriate to the circumstances, with the objective of achieving agreement or consent to the proposed measures.").

${ }^{103}$ Centre for Minority Rts. Dev. (Kenya) v. Kenya, para. 290. 
made clear its view that the state bears the burden for creating conditions favorable to a people's development. ${ }^{104}$ The state is therefore obligated to ensure that the Endorois are not left out of the development process or benefits. The African Commission agreed that because of the failure to provide adequate compensation and benefits, or to provide suitable land for grazing, the state did not adequately provide for the Endorois in the development process. Thus, the state had violated Article 22 of the Charter.

\section{SUBMISSIONS OF AFRICAN AND AMERICAN STATES IN THE KOSOVO PROCEEDINGS}

The above jurisprudence of the African and American human rights bodies is generally absent from their member states' few written submissions to the ICJ in the Kosovo proceedings. The participants from these two regions, except for Sierra Leone and the United States, contested the legality of Kosovo's declaration of independence, viewing it as a violation of Serbia's sovereignty and territorial integrity or as contrary to the relevant Security Council resolutions. These states also generally denied the existence of any right of "remedial secession." At the time the submissions were filed, the African Commission had not issued its decisions in the cases concerning Cameroon and Sudan, leaving only the early and very short opinion in the Katangese Peoples' Congress case available on the issue of secession.

Among African states, Egypt, Libya, and Sierra Leone participated in the advisory proceedings. Only Egypt referred to regional law, citing the Charter of the African Union in support of the territorial integrity of states. ${ }^{105}$ The Egyptian submission also mentioned the Sudan and Congo in expressing concern for the fragmentation of existing states, but cited UN action, not regional measures. ${ }^{106}$ Unlike the other African states, Sierra Leone submitted that it recognized Kosovo as independent and that it found both independence and the preceding declaration to be in accordance with international law. It cited no sources for its views.

Argentina, Bolivia, Brazil, the United States, and Venezuela-the Organization of American States members participating in the Kosovo proceedings—understandably made almost no reference to regional norms; the inter-American human rights system has never faced a claim of secession, and the decisions that address only internal self-determination for indigenous peoples had little relevance to Kosovo. Argentina did quote the Inter-American Commission's 1983 decision concerning the Miskitos, which denied a right to self-determination outside the colonial context. ${ }^{107}$ Without citing this early commission view, Bolivia similarly expressed its concern about extending the right of self-determination beyond the colonial context, finding no right of secession or independence for peoples living within sovereign states. Indeed, Bolivia asserted that the "fact that a State pursues a discriminatory policy against an ethnic group cannot, as such, give rise to a right to unilateral secession." The African Commission's view is rather more nuanced in finding that extreme cases of discriminatory treatment might well call into question the territorial integrity of a state.

${ }^{104}$ Declaration on the Right to Development, Art. 3, GA Res. 41/128 (Dec. 4, 1986).

105 Written Statement of the Government of the Arab Republic of Egypt, para. 34, Accordance with International Law of the Unilateral Declaration of Independence in Respect of Kosovo, Advisory Opinion (Int'l Ct. Justice July 22, 2010).

${ }^{106}$ Id., paras. 46-47.

${ }^{107}$ See supra notes $80-81$ and accompanying text. 


\section{CONCLUSIONS}

The right to self-determination as it has been applied directly by the African Commission and indirectly through the right to property in the Inter-American human rights system has emerged as a significant norm that must be taken into account in economic development projects and in governance in general. Concern for territorial integrity retains its dispositive force in most instances, limiting any claimed right to secession and independence to only the most extreme cases of massive and discriminatory violations of human rights. Yet, it is clear that the African Commission has accepted the notion of "remedial secession" and the plain meaning of African Charter Article 20(2), which guarantees external self-determination to "colonial or oppressed peoples" (emphasis added).

Apart from recognizing a right to secession and independence in extreme cases of oppression, the African Commission's jurisprudence has the potential to radically change internal governance in African states by requiring-for the benefit of the broadly defined peoples of Africa-considerably greater decentralization and public participation in decision making. The commission has been clear that prior consultations, informed consent, and benefit sharing are required when particular peoples are affected by economic development projects. If this set of requirements found to be part of the right to self-determination and the right to development is implemented across Africa, the commission will have made a major contribution to human rights and democratic governance within the region. The result may also enhance the attractiveness and stability of economic investments over time.

There remain many difficult issues with respect to the utilization of resources on indigenous and tribal lands. Subsurface mineral and water rights belong to the state in many countries, and even conveying title to indigenous peoples will not be sufficient to ensure that they are properly consulted and able to determine the nature and scope of projects affecting their lands. In addition, in some countries, communities in voluntary isolation and uncontacted indigenous peoples exist and need to be protected. The regional bodies have begun to develop the norms needed to ensure that the rights of indigenous communities are protected, especially in relation to the content and application of the right to self-determination. As so often happens in human rights law, the issue now is one of implementation and compliance.

\section{THE LEGAL EFFECTS OF UNITED NATIONS RESOLUTIONS IN THE KOSOVO ADVISORY OPINION}

\section{By Marko Divac Oberg*}

As the international community waited for the International Court of Justice (the Court) to deliver its advisory opinion of July 22,2010, commentators wondered whether the Court would skirt difficult issues by adopting a narrow reading of the question put to it. ${ }^{1}$ While the

* Legal Officer, International Criminal Tribunal for the Former Yugoslavia (marko.divac.oberg@nyu.edu). The author thanks Marko Milanovic, Anne-Thida Norodom, Yuval Shany, and Carsten Stahn for comments on earlier drafts. The opinions herein are the author's alone and do not necessarily correspond to those of the tribunal, or the United Nations in general.

${ }^{1}$ See, e.g., Marko Milanovic, Kosovo Advisory Opinion Preview, EJIL: TaLK! (July 14, 2010), at http://www. ejiltalk.org/kosovo-advisory-opinion-preview. 